\title{
Barnett and the Constitution We Have Lost
}

\author{
STEPHEN M. GRIFFIN*
}

TABLE OF CONTENTS

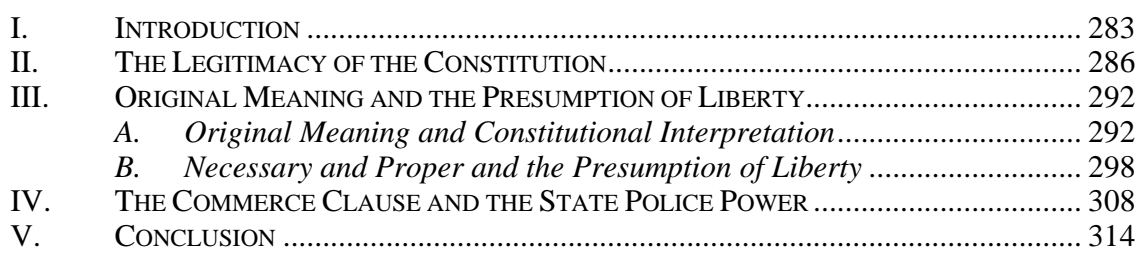

\section{INTRODUCTION}

In Restoring the Lost Constitution: The Presumption of Liberty, ${ }^{1}$ Randy Barnett begins by recalling his disillusionment as a Harvard law student with the study of constitutional law. Once he finished Professor Laurence Tribe's Constitutional Law course, he was "finished with the Constitution as well. The idea of protecting liberty by imposing written constraints on the government was an experiment that obviously had failed." ${ }^{2}$

* Rutledge C. Clement, Jr. Professor in Constitutional Law, Tulane Law School.

1. Randy E. Barnett, Restoring the Lost Constitution: The Presumption OF LIBERTY (2004).

2. Id. at $\mathrm{x}$. 
I think this somewhat idealistic reaction is not uncommon. As a student, Barnett had expectations about constitutional law-that it should be about keeping government within strict limits guarded vigorously by the judiciary - that were not redeemed. He now seeks to rescue constitutional law by turning the widely accepted presumption of constitutionality into the "presumption of liberty." From Barnett's point of view, adopting the presumption of liberty is required to recover the original meaning of the necessary and proper clause, the Ninth Amendment, and the privileges or immunities clause of the Fourteenth Amendment as well as to provide protection for all enumerated and unenumerated constitutional liberties. In making his case, Barnett provides the most detailed and coherent theory for a libertarian constitutional order with which I am familiar. Everyone interested in American constitutional law and theory should read this intriguing book.

Barnett has calibrated his theory carefully to avoid some of the problems common to "conservative" and libertarian theories. He rejects the kind of originalism that looks for a subjective intent in favor of the "original meaning" (or original understanding) approach that scrutinizes the public meaning of the text of the Constitution. He celebrates the rights-creating potential of the Ninth Amendment and pays close attention to the Fourteenth Amendment. ${ }^{3}$ Barnett's theory might be described as "all rights, all the time." He embraces "liberal" rights such as the right to privacy and the right to travel while also insisting on strong protection for rights of contract and property. He takes full advantage of recent historical scholarship that shows that the jurisprudence of the Lochner era was far closer to the values of the founding generation than most legal scholars have assumed. ${ }^{4}$

Despite the care with which Barnett has constructed his theory, I suspect many legal scholars will be dismissive when they learn that he calls for a return to pre-New Deal understandings of the Commerce and Due Process Clauses, as well as the application of something close to strict scrutiny of all federal and state legislation. Indeed, Barnett's book can be regarded as a sort of time capsule of what constitutional law might have looked like had the Great Depression and the New Deal not intervened. But it would be unfortunate if this reaction prevented scholars from coming to grips with Barnett's approach to constitutional

3. Barnett, however, barely mentions the Equal Protection Clause.

4. See Howard Gillman, The Constitution Besieged: The Rise and Demise OF LOCHNER ERA POLICE POWERS JuRISPRUDENCE 10 (1993) (viewing Lochner-era cases as a "serious, principled effort to maintain one of the central distinctions in nineteenthcentury constitutional law - the distinction between valid economic regulation, on the one hand, and invalid 'class' legislation on the other"). 
law. For scholars who value the document over the doctrine, ${ }^{5}$ Barnett's textual purism has its attractions. At least from the perspective of constitutional theory, there are some valuable lessons to be learned from Barnett's libertarian approach, especially with respect to the importance of informal constitutional change in shaping American constitutionalism. ${ }^{6}$

The strengths of Barnett's theory include his close attention to parts of the Constitution that have been neglected, a calm and even conversational tone, his clear-headed exposition, and the theory's unity and coherence. The weaknesses are more difficult to summarize in brief. Barnett's book provides evidence that it is not possible to argue for a libertarian approach to the Constitution simply by offering an interpretation of its text. Barnett's argument depends on a controversial theory of political legitimacy brought in from outside the text in order to ensure that the nonlibertarian elements in American constitutionalism do not prevail. This need to rely on an external theory of legitimacy makes Barnett's argument vulnerable to various important objections. In addition, Barnett is in love with the idea of thinking about the Constitution as if it were a commercial contract, an especially implausible approach. Further, his "original meaning" theory of interpretation is open to standard objections that he does not consider. Finally, Barnett's theory is afflicted by a certain historical weightlessness. ${ }^{7}$ In effect, he takes issue with those progressives who objected to Lochner-era jurisprudence and New Dealers who sought to change the constitutional order without considering their reasons. At the same time, it should be said that Barnett's theory at least enables us to gauge how far we have come from some of the normative commitments that underlay the 1787 Constitution.

I will consider Barnett's book in three stages. In Part II, I criticize the external theory of political legitimacy that Barnett applies to the Constitution. I argue that this theory had nothing to do with the actual reasons the Constitution was accepted as legitimate when it was ratified. In Part III, I focus on Barnett's theory of constitutional interpretation and his account of the Necessary and Proper Clause, the foundation of the

5. See Akhil Reed Amar, The Supreme Court, 1999 Term-Foreword: The Document and the Doctrine, 114 HARV. L. REV. 26, 133 (2000) (arguing that a "dense doctrinal grid threatens to obscure" the Constitution itself).

6. This is an important theme in my own work. See, e.g., Stephen M. Griffin, Constitutional Theory Transformed, 108 YALE L.J. 2115, 2119 (1999) (arguing that the response to the Great Depression forced most constitutional change "off text" in the form of political change).

7. I am grateful to Keith Whittington for this point. 
"presumption of liberty.” I also critique Barnett's treatment of the Lochner era. In Part IV, I examine Barnett's approach to governmental power under the Constitution, particularly with respect to the Commerce Clause and the state police power.

\section{THE LEGITIMACY OF THE CONSTITUTION}

It might be thought that a theory that argues that the Constitution is more libertarian than most Americans think would have to focus first on showing how a reasonable interpretation of the text yields this result. Yet in Part I of his book, Barnett begins with the political theory behind the idea of government by consent. He asks whether the Constitution is binding on us and is thus legitimate. ${ }^{8}$ In Barnett's account, a constitution is legitimate if it creates a legal system in which citizens have a moral duty to obey the law. ${ }^{9}$ He asks, "is one morally obligated to obey any law that is enacted according to constitutional procedures?"10 The standard answer to this question within American constitutionalism is yes because "We the People" have consented to the Constitution and our form of government. Barnett objects that the conditions for actual consent have never been met and could never be met. ${ }^{11}$ Therefore, he contends that if the Constitution is to be found legitimate, it must be on grounds other than actual consent. ${ }^{12}$

The fact that Barnett begins with political theory rather than constitutional interpretation is highly significant. This suggests that a libertarian approach to the Constitution cannot get off the ground without the help of an external political theory. But if the political theory of consent Barnett spins out does not have any substantial relationship to the Constitution, then we should question whether he is indeed providing us with a reliable account of the Constitution we actually have.

Barnett examines and rejects various bases for contending that we have actually consented to obey the law. One argument is that voting constitutes consent to obey the law. ${ }^{13}$ Another argument is that residency implies consent. ${ }^{14}$ Still another is that we are bound by the consent of the founders. ${ }^{15}$ This last argument is essentially an invocation of the doctrine of popular sovereignty and is a familiar element of the

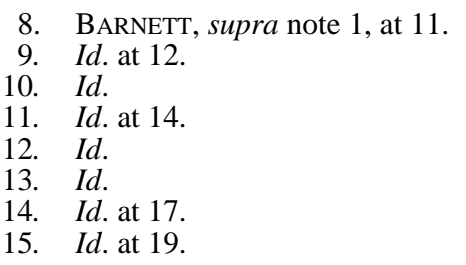


American constitutional tradition. But Barnett challenges this argument. The Constitution, he says, was not approved by a unanimous vote or even a majority vote of all the people. ${ }^{16}$ Instead, it was approved by a majority of delegates to constitutional conventions. Barnett asks, "How can a small minority of inhabitants presuming to call themselves 'We the People’ consensually bind anyone but themselves?"17 For Barnett, consent of the minority or the individual cannot be inferred from the consent of the majority. ${ }^{18}$ No person can consent for another and thus the "consent of the governed" can work only if unanimous consent is obtained. $^{19}$

A key assumption behind Barnett's analysis is that the kind of consent required in the constitutional context is the same as the consent required to make a contract. Barnett argues that having a "rule of recognition"-a sense that a legal system exists and is acquiesced to-is different from legitimacy. ${ }^{20}$ Ratification conventions can indeed supply an effective rule of recognition. ${ }^{21}$ But acquiescence to a legal order does not yield the kind of "moral duty" required by Barnett. ${ }^{22}$ Only actual consent by each and every individual can overcome this difficulty.

Because unanimous consent is impossible in any practical constitutional order, consent must be replaced by an inquiry into whether the laws that are passed by the legal authorities are both necessary and proper. ${ }^{23}$ So Barnett will not condemn the Constitution to illegitimacy; rather, he will show how it is legitimate for reasons other than consent and popular sovereignty. He will establish the essential conditions for constitutional legitimacy. ${ }^{24}$

I see two immediate problems with Barnett's theory of constitutional legitimacy. First, Barnett assumes that the key issue is the personal moral legitimacy of the Constitution to each and every individual rather than the political legitimacy of the Constitution to the people as a whole. ${ }^{25}$ Second, Barnett ignores the standard historical account of the

16. Id. at 20

17. Id.

18. Id. at 21

19. Id. at 21-22.

20. Id. at 22-23.

21. Id. at 23 .

22. Id.

23. Id. at 24

24. Id. at 31 .

25. On the differences between moral and political obligation, see REX MARTIN, A SYSTEM OF RigHTS 5-23 (1993). 
meaning of popular sovereignty. ${ }^{26}$ History leaves little doubt that the theory of legitimacy behind the Constitution was political, not moral (at least not moral in Barnett's sense), and that the legitimacy of the Constitution was achieved on a collective, rather than an individualistic basis. $^{27}$

Barnett is puzzled by the eighteenth century concept of popular sovereignty. He asks how the founding generation could believe simultaneously in the "fiction" ${ }^{28}$ of popular sovereignty and at the same time distrust the people when they were divided into majority and minority factions. ${ }^{29}$ Unfortunately, Barnett does not discuss the historical meaning of popular sovereignty - that it was a way for the founding generation to express the extraordinary and indeed extralegal process by which the republic was founded. ${ }^{30}$ Critically, the founding generation learned how to put the abstract concept of popular sovereignty into practice by inventing the constitutional convention. ${ }^{31}$ It was this concrete institutionalization of sovereignty that is especially relevant to understanding why the Constitution was accepted as politically legitimate.

With respect to constitutional conventions, Barnett says that ratification of the Constitution by such conventions "may contribute to, though not establish"32 its legitimacy. He says that such a ratification process would have assured the people who participated in the process that the resulting legal system was legitimate. ${ }^{33}$ However, this "partial consent" ${ }^{34}$ through constitutional conventions was neither sufficient nor necessary to provide legitimacy to our legal system. ${ }^{35}$ For Barnett, ratification through constitutional conventions was not sufficient to establish the legitimacy of the Constitution because it did not provide a way in which literally each and every person in the United States could give or withhold his or her consent.

Whatever one thinks of this theory of legitimacy by individual consent, it clearly has nothing to do with the normative reasons why the

26. See, e.g., Samuel H. Beer, To Make a Nation: The Rediscovery of American Federalism 322-40 (1993); R.R. PALmer, 1 The Age of the Democratic REvOlution 213-35 (1959); Gordon S. WOOD, THE CREATION OF THE AMERICAN REPUBLIC, 1776-1787, at 382-83, 530-32, 596-600 (1969).

27. On the point that sovereignty was a collective concept, see WoOD, supra note 26 , at 382 .

28. BARNETT, supra note 1 , at 36 .

29. Id.

30. See WooD, supra note 26, at 306-43, 382-83.

31. See Akhil Reed Amar, Of Sovereignty and Federalism, 96 YALE L.J. 1425, 1459-62 (1987).

32. BARNETT, supra note 1 , at 77 .

33. Id.

34. Id. at 78 .

35. Id. 
Constitution was accepted as legitimate in the eighteenth century. Perhaps, however, Barnett means to judge the ratification process by the standards of a particular political theory in which he happens to believe. There is nothing wrong with this per se, but it fits badly with the overall thrust of his argument. Barnett's starting point is that governmental legitimacy in the United States has traditionally been founded on the consent of the governed. The fact that Americans accept government by consent, however, certainly does not mean that they accept Barnett's theory of government by unanimous consent. As far as I can tell, no one in the eighteenth century advocated Barnett's theory. Barnett therefore cannot claim that his particular theory of consent has anything to do with traditional American standards for legitimate government.

To put the point another way, Barnett builds a straw man and then knocks it down. He claims that "[t]hose who justify a duty to obey the law on the basis of the 'consent of the governed' must explain exactly how and when 'We the People' - you and me and everyone else-consented to obey the laws of the land." 36 This statement well illustrates Barnett's view that the consent of the governed means the actual consent of each and every individual in the polity. There is no prima facie reason, however, why someone who believes that the Constitution was made legitimate through popular sovereignty and ratification by constitutional conventions has to meet this burden. The eighteenth century theory of popular sovereignty certainly was not based in such a radically individualistic account of consent.

The eighteenth century theory of popular sovereignty or legitimacy was a political theory that rested on the idea that government derived "all its powers directly or indirectly from the great body of the people."37 Such a collective body could act through special assemblies called constitutional conventions to ratify a proposed constitution. Once ratified, the Constitution would operate as the fundamental law of the land and would be accepted as such by all. This normative theory is close to what actually occurred following the signing of the Constitution in 1787. Close enough so that the American people accepted the Constitution as legitimate.

Why is Barnett so concerned with individual (as opposed to collective) consent? Barnett states that individuals have fundamental natural,

36. Id. at 14

37. The Federalist No. 39, at 251 (James Madison) (Jacob E. Cooke ed., 1961). 
human, or background rights (it does not matter much to him what they are called) and for those rights to be effective, people must have a further right to withhold their consent to a lawmaking process. ${ }^{38}$ So rights precede government. Lawmaking, however, can be legitimate in the absence of consent if it is just; that is, if it is "(1) necessary to protect the rights of others and (2) proper insofar as [it does] not violate the preexisting rights of the persons on whom they are imposed."39

Barnett contends that the founding generation believed in natural rights, although he writes that there was not universal agreement about the content of those rights or the remedy for their violation. ${ }^{40}$ Further, natural rights were synonymous with the various liberties the people have before a government is formed. ${ }^{41}$ Here, the Ninth Amendment enters the picture. The purpose of the Ninth Amendment was to guard against the possibility that the enumeration of rights in the Bill of Rights would be taken to mean that the other liberties had been given up. ${ }^{42}$ The Privileges or Immunities Clause of the Fourteenth Amendment also operates to guarantee these natural rights or liberties. ${ }^{43}$ Barnett argues that the founding generation was correct to believe in some form of natural rights. ${ }^{44}$ Such rights ensure a sphere of "bounded freedom" 45 -in which individuals pursue their own ends by using "the rights of several property, freedom of contract, first possession, self-defense, and restitution." 46

Throughout his argument on constitutional legitimacy and, indeed, much of the rest of the book, Barnett assumes that the Constitution should be analyzed as if it were a commercial contract. ${ }^{47}$ This assumption is deeply mistaken. Contracts have a superficial similarity to constitutions in that both are agreements reduced to writing. Focusing on agreement, however, does not isolate what makes contracts special and useful. Commercial contracts are about exchange in the context of a market economy. Focusing on agreement also does not isolate what makes constitutions special. Constitutions structure politics and governmental institutions. As I have argued elsewhere, they are a distinctive political practice. ${ }^{48}$

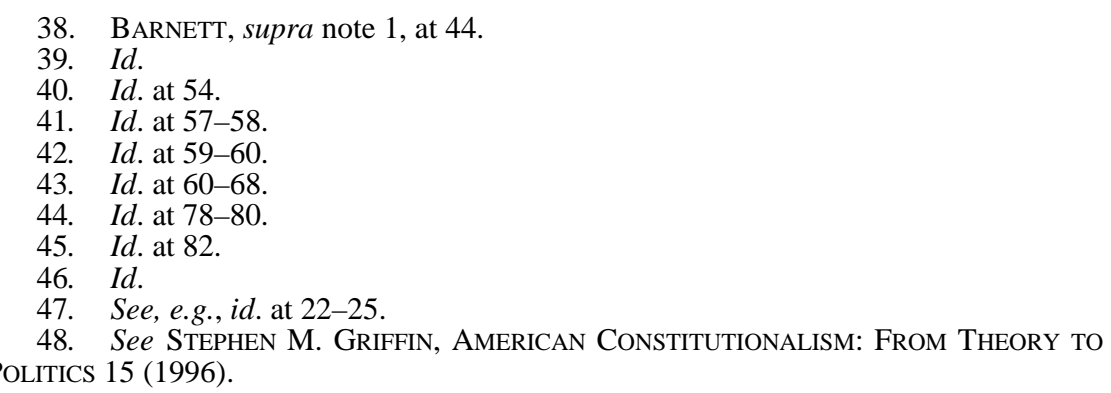


Russell Hardin has usefully elaborated the differences between the Constitution and a contract. ${ }^{49}$ Hardin first draws a distinction among theories of social order based on conflict, shared values, exchange, and coordination. $^{50}$ He argues that coordination theory is especially well suited to understanding the purpose of the American Constitution. Hardin emphasizes: "A constitution does not resolve a particular exchange .... It regulates a long-term pattern of interactions. It establishes conventions in the sociological or strategic sense that make it easier for us to cooperate and to coordinate in particular moments." ${ }^{\text {" }}$ Constitutions help bring institutions like contracting into existence. Hardin discusses two other differences between a constitution and a contract: while agreement is necessary for contracts, acquiescence is more important for constitutions; further, contracts are enforced through external sanctions while constitutions are self-enforcing. ${ }^{52}$

In support of his second point, Hardin notes that "[t]o come into being or to be effective, a constitution does not require universal or even widespread agreement." 53 One of the advantages of the 1787 Constitution is that it did not require the unanimous consent of the states, unlike the ill-fated Articles of Confederation. ${ }^{54}$ Obviously, many Americans did not in any way signal their acceptance of the Constitution. One of the virtues of Hardin's argument is that he is able to explain why the Constitution was a success even though it lacked unanimous agreement. As he states:

\section{A constitution does not commit the way a contract does. Rather it merely raises the cost of trying to do things some other way through its creation of a coordination convention. Moreover what it commits to is open to evolution and change in a far more expansive way than is the expectation of action under a contract. ${ }^{55}$}

Once the Constitution began operating and showed some initial benefits, it could not be supplanted in the same way as the Articles of Confederation. Its success bred more success. As Hardin comments: "The Constitution of 1787 worked in the end because enough of the

49. See Russell Hardin, Liberalism, Constitutionalism, AND Democracy 82140 (1999).

50. See id. at 9-12.

51. Id. at 86 .

52. Id. at 88-89.

53. Id. at 107.

54. Id.

55. Id. at 111-12. 
relevant people worked within its confines long enough to get it established in everyone's expectations that there was no point in not working within its confines." 56

Comparing the Constitution to a contract is also misleading because it implies that the Constitution is like an ordinary law. As I have argued elsewhere, there are significant disanalogies between ordinary laws and the Constitution. ${ }^{57}$ First, the Constitution is the framework for the entire government and, as such, provides the structure for national politics as a whole. Second, many of the Constitution's most significant provisions are written in terms far more abstract than those commonly used in ordinary law (or contracts). Third, as Hardin emphasizes, the Constitution cannot be enforced in the same way other laws can. ${ }^{58}$ When someone violates a contract, some external agency stands ready to enforce the contract and remedy the violation. By contrast, constitutions must be self-enforcing. In the constitutional sphere, there is no external agency available (if there were, it would not itself be subject to the constitution). Without an external agency, constitutions must ultimately be enforced by the operation of the entire political system or, one might say, by the people as a whole.

Because the Constitution is not analogous to a contract, Barnett's entire theoretical enterprise has difficulty getting off the ground. First, his assumption that we must consent to the Constitution as we do to a contract does not hold and so the theory of legitimacy that follows from this assumption is therefore unsound. Second, as I demonstrate below, the notion of the Constitution as contract causes Barnett to ignore the idea of the "living Constitution," a well-known alternative to his account of constitutional interpretation. This ultimately weakens the plausibility of Barnett's theory of interpretation and thus his libertarian approach as a whole.

\section{ORIGinal MEANing AND the PRESUMPTION OF LIBERTY}

\section{A. Original Meaning and Constitutional Interpretation}

Having established to his satisfaction that the purpose of government is to protect the natural rights of liberty, Barnett moves to a consideration of the kind of constitutional method necessary to realize these rights. Barnett defends a version of originalism known as "original meaning," which, in brief, focuses on the objective meaning that the words of the

56. Id. at 136 .

57. See GRIFFIN, supra note 48, at 13-15.

58. See HARDIN, supra note 49, at 88-89; see also SYlVIA SNOWISS, JUdICIAL REVIEW AND THE LAW OF THE CONSTITUTION 5-6, 198-99 (1990). 
Constitution had when it was written as opposed to the subjective intent of the framers. ${ }^{59}$ Barnett views originalism as following from the foundational commitment to have a written constitution and, like many originalists I have read, does not recognize any viable alternative method of interpretation. ${ }^{60}$ Barnett thinks that the most important reason some scholars oppose originalism is because they do not like its consequences for constitutional doctrine. ${ }^{61}$ He draws a distinction between what the Constitution says and whether we approve of it. He contends that we should not choose a method of interpretation because of the outcomes it recommends. That "puts the evaluative cart before the interpretive horse."62

In keeping with his general theory, Barnett uses principles from contract law to illuminate constitutional interpretation. ${ }^{63}$ He argues, in an uncharacteristically weak fashion, that the fact that the Constitution is written makes contract law relevant given that contracts are in writing. ${ }^{64}$ The original meaning approach to constitutional interpretation follows from "the commitment to a written text." 65 Barnett highlights the importance of "locking in" legal meaning. Constitutions are put in writing in order to restrict future lawmakers and thus lock in a particular legal order. ${ }^{66}$ Here Barnett develops a useful counter to those who see the Constitution as a living document. He brings contract principles and constitutional interpretation together in a fruitful way:

With a constitution, as with a contract, we look to the meaning established at the time of formation and for the same reason: If either a constitution or a contract is reduced to writing and executed, where it speaks it establishes or "locks in" a rule of law from that moment forward. Adopting any meaning contrary to the original meaning would be to contradict or change the meaning of the text and thereby to undermine the value of writtenness itself. Writtenness ceases to perform its function if meaning can be changed in the absence of an equally written modification or amendment. ${ }^{67}$

\footnotetext{
59. BARNETT, supra note 1 , at $89,92$.

60. Id. at 92 .

61. Id. at 96 .

62. Id.

63. Id. at 97, 100 .

64. Id. at 100. This syllogism seems a bit incomplete. The fact that the Qur'an is in writing does not mean that its interpretive principles are relevant to American constitutional interpretation. A closer relationship to the Constitution must first be established before this argument can get off the ground.

65. Id.

66. Id. at 103-05.

67. Id. at $105-06$.
} 
In developing this interesting perspective on constitutional interpretation, Barnett does not come to grips with any significant opposing view. ${ }^{68}$ This is unfortunate, because interpretation is the area of constitutional theory to which scholars have devoted the greatest attention. Despite the wide variety of theories of interpretation, advocates of originalism like Barnett have tended to assume that it is the status quo. ${ }^{69}$ This is clearly mistaken, because it has not been the practice of the Supreme Court to adopt any one method of interpretation. ${ }^{70}$

The most accurate description of the Supreme Court's practice is that it uses a plurality of methods of interpretation. These different methods are the product of the reality that there are various authoritative sources of law in the United States. Each theory of interpretation is grounded in a recognized source of law and draws strength from the authority of that source. ${ }^{71}$ Barnett's theory illustrates this perfectly. Barnett employs contract law to ground constitutional law. He appeals to our sense that we live in a common law system and to a plausible, although flawed, analogy between the Constitution and a contract.

Although constitutions are not like contracts, there is nothing wrong with the idea of illuminating the Constitution with principles drawn from other areas of American law. It illustrates the process I have described as the "legalization" of the Constitution. ${ }^{72}$ Where Barnett goes wrong is to assume, without any real argument, that his preferred method of interpretation is the only legitimate method. The idea of a plurality of methods, however, has been previously explored in depth by Philip Bobbitt, Richard Fallon, Robert Post, and in my own work. ${ }^{73}$ Their theories converge around the following methods of interpretation: textualism, history, precedent, inferences from the structure of the Constitution, and tradition. ${ }^{74}$

Barnett's theory is compatible with two of the methods actually used by the Supreme Court: text and history (although, for Barnett, history is defined as the search for original meaning). He does not mention any other method of interpretation. This could be construed as a call for

68. For example, he remarks that "the opponents of originalism have never converged on an appealing and practical alternative.” Id. at 92. Leaving to one side the issue of why opponents of originalism must converge before Barnett is required to discuss their theories, this ignores the important practical question of whether the theory of original meaning is actually followed by the Supreme Court, and if it is, whether it is regarded by the Court as the only legitimate theory of interpretation as Barnett assumes. 157-58.

69. Barnett is thus vulnerable to the criticism I made in GRIFFIN, supra note 48, at

70. Id. at $146-47$.

71. I have developed this argument at length in id. at 143-52.

72. See id. at 144-47.

73. See id. at $143-52$

74. Id. at 148 . 
changing the status quo, except that Barnett does not recognize that the status quo includes more methods than the one he favors. So he does not provide the kind of argument in favor of original meaning that he needs to. The point is not to establish that original meaning is a legitimate theory of interpretation. In light of the development of the American constitutional tradition, there is no doubt that it is. Barnett's burden is to establish why it is the only legitimate method of interpretation. Barnett evades this burden by assuming, as many other originalists have done, that original meaning is the status quo. This is clearly false.

Barnett is also wrong to say that the only reason scholars oppose originalism is because of its consequences for doctrines they like. Scholars have argued that originalism is just as implausible as it is harmful. ${ }^{75}$ First, for the reasons I have reviewed, originalism is not the only legitimate method of constitutional interpretation. Second, scholars have argued that originalism is a poor fit with much existing constitutional doctrine-it does not explain that doctrine and does not reflect the standard practice of the Supreme Court. Third, scholars likely regard originalism as less plausible than the theory they think is most plausible- the idea that the Constitution is a "living" document. ${ }^{76}$

The idea of a living Constitution was well stated by Justice William Brennan: "[T]he genius of the Constitution rests not in any static meaning it might have had in a world that is dead and gone, but in the adaptability of its great principles to cope with current problems and current needs."77 It is important to understand that a major element of the power of the living Constitution perspective is that it accords with a widespread understanding of how the American constitutional system has developed over time. That is, the living Constitution perspective is accepted not just because it is perceived as normatively desirable, but because it is understood to be an accurate description of how American constitutionalism has actually worked. ${ }^{78}$

75. See, e.g., Richard H. FAllon, JR., The Dynamic CONSTITUTION: AN INTRODUCTION TO AMERICAN CONSTITUTIONAL LAW 196-97 (2004); DANIEL A. FARBER \& Suzanna Sherry, Desperately SeEking Certainty: The Misguided Quest for CONSTITUTIONAL FOUNDATIONS 11-21 (2002).

76. See, e.g., FALLON, supra note 75, at 240, 269-70.

77. William J. Brennan, Jr., The Constitution of the United States: Contemporary Ratification, in INTERPRETING THE CONSTITUTION: THE DEBATE OVER ORIGINAL INTENT 23, 27 (Jack N. Rakove ed., 1990).

78. See Gordon S. Wood, The Fundamentalists and the Constitution, 35 N.Y. REv. BooKs, Feb. 18, 1988, at 33, 39. This point is well illustrated in Robert C. Post, The Supreme Court, 2002 Term-Foreword: Fashioning the Legal Constitution: Culture, 
It is telling that Barnett never discusses the living Constitution perspective as an alternative to originalism. From this perspective, it is not possible to "lock in" the Constitution's most famous abstract provisions. The meaning of the Constitution changes not only because the circumstances to which it is applied change, but as the values and beliefs that inform the text change. ${ }^{79}$ Barnett wonders, in effect, why anyone who accepts this perspective would be interested in adopting a text that is difficult to amend. ${ }^{80}$ Why not just make up the Constitution as you go along? I can imagine a number of replies here, but the most fundamental one is that living constitutionalists do not understand the Constitution to be a contract. In general, the purpose of the Constitution is to frame the government, not to freeze in place a specific governing regime. The Federalists believed in one sort of regime, Jeffersonians another, and New Deal Democrats yet a third. Fortunately for the stability of our government, the Constitution's broad generalities were compatible with all three. From a living Constitution perspective, abstract language, not suitable for ordinary contracts, is appropriate in the constitutional case.

The contrast between Barnett and living constitutionalists illustrates why I think the theory of constitutional change is fundamental for constitutional theory. ${ }^{81}$ Barnett's lockbox theory of constitutional meaning illustrates the important role of constitutional change very well. Barnett's implied criticism of the living Constitution perspective is that one cannot hold this view without committing the error of amending the Constitution outside the procedures specified in Article V. Barnett's view of how legitimate constitutional change occurs is thus a key element in his argument for interpreting the Constitution by using original meaning.

I have taken a somewhat detached perspective on the idea of the living Constitution because it has many strands, not all of which I agree with. Living constitutionalists often respond to Barnett's challenge of "Why bother to have a written text?" by saying that it is important to have a continuous and vital constitutional tradition. New interpretations are legal

Courts, and Law, 117 HARv. L. Rev. 4, 35-41 (2003). As Post states: “The question is not whether constitutional culture ought to be a source of constitutional law, because as a matter of history and structure constitutional interpretation is possible only because the Court engages in a continuous dialogue with the constitutional beliefs and values of nonjudicial actors.” Id. at 41.

79. See Griffin, supra note 6, at 2148-56.

80. It is useful to compare Barnett's theory to Christopher Eisgruber's on this important point. See CHRISTOPHER L. EISGRUBER, CONSTITUTIONAL SELF-GOVERNMENT 10-25 (2001). Eisgruber contends that "we should regard inflexible written constitutions, including the American one, as practical, procedural devices for implementing relatively ordinary, albeit non-majoritarian, conceptions of democracy.” Id. at 11. Eisgruber thus argues that the purpose of an inflexible constitution is not primarily to bind future lawmakers (as Barnett would have it) but to guarantee democratic self-government.

81. See GRIFFIN, supra note 48; Griffin, supra note 6. 
to the extent that they are consistent with the broad outlines of the Constitution and to its historical traditions. Further, there is no point to amending the Constitution every time an unforeseen circumstance occurs because the genius of the document is precisely that it can serve to structure the government although more than two centuries have passed since its adoption.

Matters look somewhat different from my historicist perspective. Instead of a continuous constitutional tradition, I have argued that the constitutional order has been broken and remade in various fundamental respects at several points in American history, most notably during Reconstruction and the New Deal. ${ }^{82}$ So my answer to Barnett on the question "Why have a Constitution?" is not the same as the answer given by the living constitutionalists. To me, our constitutional "tradition" has discontinuities that are just as important to understanding American constitutionalism as are the continuities relied on by Barnett and the living constitutionalists. ${ }^{83}$

Further, the whole question of why we cannot amend the Constitution every time there is a significant change in circumstances is for me a far more complex matter than it is for Barnett or the living constitutionalists. One answer to Barnett is that we cannot amend the Constitution in the way he suggests without endangering the stability of our form of government. In general, Barnett underestimates the difficulty of amending the Constitution ${ }^{84}$ and he does not review the reasons (presented by James Madison in Federalist No. 49) ${ }^{85}$ why it is useful to have a document that is difficult to amend. Someone who wants to be "up front" about making a significant change to the Constitution in the manner Barnett recommends is faced by a host of problems. Americans often take suggestions for important constitutional amendments to be criticisms of our entire form of government (indeed, our way of life), not as reasonable reforms in the light of changing circumstances (as Barnett would have it). Because the Constitution is the focus of strong patriotic sentiments, it is difficult to change even when such a change is necessary. ${ }^{86}$ This forces responsible constitutional actors to seek means of constitutional change other than amendment, including judicial

82. See GRIFFIN, supra note 48, at 36; Griffin, supra note 6, at 2115-16.

83. Griffin, supra note 6 , at 2148.

84. BARNETT, supra note 1 , at 351 .

85. I review these reasons in GRIFFIN, supra note 48, at 29-30.

86. Id. at 39 . 
interpretation and ordinary politics. ${ }^{87}$

Barnett states that not all constitutional provisions will be susceptible to originalist interpretation. Provisions that are vague or abstract must be construed, rather than interpreted, when applied to new circumstances outside their core meaning. ${ }^{88}$ Barnett employs Keith Whittington's concept of constitutional "construction" 89 to fill in the gap between vague provisions and cases unforeseen by the framers. ${ }^{90}$ Such construction should be guided by originalist methods and constitutional principles such as separation of powers and federalism. ${ }^{91}$ The political question doctrine is an example of a construction of the Constitution. ${ }^{92}$ According to Barnett, Chief Justice John Marshall's opinion in Marbury v. Madison ${ }^{93}$ is another clear example of constitutional construction. ${ }^{94}$ But perhaps most important for Barnett's overall argument, the presumption of constitutionality itself is a constitutional construction, rather than an interpretation of the Constitution. ${ }^{95}$ This makes it easier from him to argue that it should be replaced by the presumption of liberty.

\section{B. Necessary and Proper and the Presumption of Liberty}

Barnett now moves to his central concern: replacing the presumption of constitutionality normally accorded by the judiciary to legislation with the "presumption of liberty." To do this, he must first undermine the traditional interpretation of the Necessary and Proper Clause. ${ }^{96}$ Barnett notes that Federalists maintained that the clause "was not an additional freestanding grant of power, but merely made explicit what was already implicit in the grant of each enumerated power."97 He then reviews the famous 1791 debate over the constitutionality of a national bank, devoting particular attention to the views of then-Representative James Madison. ${ }^{98}$ Barnett does not say as much about the opinions offered by Secretary of the Treasury Alexander Hamilton ${ }^{99}$ and Chief

87. Id. at 45 .

88. See BARNETT, supra note 1 , at 119-20.

89. Keith E. Whittington, Constitutional Construction: Divided Powers AND CONSTITUTIONAL MEANing 1-2 (1999).

90. BARNETT, supra note 1 , at 121-22.

91. Id. at 125 .

92. Id. at 129 .

93. 5 U.S. (1 Cranch) 137 (1803).

94. BARNETT, supra note 1 , at 144-47.

95. Id. at $151-52$.

96. U.S. CONST. art. I, § 8, cl. 18.

97. BARNETT, supra note 1 , at 155.

98. Id. at $158-64$.

99. See 8 The PAPERS Of AlexANDER HAMilton 97-134 (Harold C. Syrett et. al. eds., 1965). 
Justice Marshall in McCulloch v. Maryland, ${ }^{100}$ often taken by scholars to be the sine qua non of constitutional arguments. ${ }^{101}$ Because most judges and scholars have found these opinions persuasive, Barnett's road in opposing them is steeply uphill all the way. ${ }^{102}$

Unfortunately, Barnett's overall argument and his account of the 1791 debate are quite partial ${ }^{103}$ and do not, for example, take into consideration the persuasive replies made in the House of Representatives to Madison's argument against the bank. ${ }^{104}$ Ironically, those replies drew on Madison's own defense of the Necessary and Proper Clause in Federalist No. 44. ${ }^{105}$ There, Madison stated: "Without the substance of this power, the whole Constitution would be a dead letter." ${ }^{106}$ The main problem with Barnett's argument is that the House of Representatives and the Senate of the United States, both crowded with framers and ratifiers of the 1787 Constitution, accepted the constitutional arguments of the supporters of the bank and rejected Madison's newfound concerns. This is strong evidence that the original meaning of the Necessary and Proper Clause supported the constitutionality of a national bank and that Barnett's position was considered and rejected in 1791.

But there is more. After the bank bill passed Congress, President George Washington asked his advisors for their constitutional opinions. ${ }^{107}$ Attorney General Edmund Randolph and Secretary of State Thomas Jefferson argued against the constitutionality of the bank. ${ }^{108}$ As I have

100. 17 U.S. (4 Wheat.) 316 (1819).

101. See BARNETT, supra note 1, at 166-71. On the high esteem in which Hamilton's argument is held, see Richard B. BERnstein \& KyM S. Rice, ARE WE TO BE A NATION?: THE MAKING OF THE CONSTITUTION 256 (1987).

102. Barnett does say that Marshall's opinion in McCulloch can be read to support a more circumscribed view of the necessary and proper power than is common. BARNETT, supra note 1, at 176-77. He argues that the clause was thought to be justiciable. Id. at 178. But because of McCulloch's vast influence, "the enumeration of powers has largely been vitiated as a limitation on the scope of the national government . ..." Id. at 183.

103. Id. at 158-66.

104. For more complete accounts, see DAVID P. CURrie, The Constitution IN CONGRESs 78-80 (1997); STANLEy ELKINS \& ERIC MCKITRICK, THE AGE OF FEDERALISM 226-34 (1993).

105. ThE Federalist No. 44, at 302-05 (James Madison) (Jacob E. Cooke ed., 1961).

106. Id. at 303.

107. For a good recent discussion of the advisory opinions on the bank, see $\mathrm{H}$. JefFerson Powell, A COMmunity Built on Words: THE CONSTitution in History AND POLITICS 21-30 (2002).

108. BARNETT, supra note 1 , at 165-66. 
noted, Hamilton argued in favor. ${ }^{109}$ President Washington was convinced by Hamilton's arguments and signed the bill into law. At a minimum, this shows that there is strong evidence that the original meaning of the necessary and proper clause is not what Barnett says it is. More important, it is very unlikely that President Washington, the "Father of our Country," would have signed the bank bill had it been obvious (as Barnett would have it) that the bank violated the original meaning of the Constitution.

I agree with Barnett that Chief Justice Marshall's view of the Necessary and Proper Clause did not make it into a de facto grant of plenary power to the federal government. McCulloch might be read that way by contemporary judges and scholars, but, as Barnett says, there are many indications that this is not how Marshall understood his opinion. ${ }^{110}$ But it does not follow that accepting Hamilton's justification of the constitutionality of the bank meant that the doctrine of enumerated powers was dead. It turned out that the national government had more constitutional power than Jefferson and Madison were willing to acknowledge in the 1790s. Both men, however, had occasion to revisit the issue of national power in a way that ultimately showed Hamilton had the better of the argument-Jefferson endorsed the constitutionally questionable Louisiana Purchase and Madison eventually endorsed the national bank. ${ }^{111}$

Barnett, however, does believe that accepting Hamilton's interpretation of the Necessary and Proper Clause means that the judiciary cannot appropriately oversee the exercise of constitutional power. Here Barnett makes an argument about judicial deference that appears throughout the book. Allowing lawmakers the authority to change constitutional meaning implies that they can determine the scope of their own authority and so "places the rights of everyone at peril."112 By Barnett's logic, this means that once a clause, such as the Necessary and Proper Clause, is shown to be justiciable, it follows that deferential review by the judiciary is

109. Barnett does not really respond to Hamilton's arguments. He says that in evaluating Hamilton's argument, we should keep in mind that Hamilton argued for an extreme form of consolidated government at the Federal Convention. Id. at 167. But Hamilton apparently retained the confidence of the Convention, participating on the Committee on Style and Arrangement near the end of the Convention. BERNSTEIN \& RICE, supra note 101, at 197. Further, as co-author of The Federalist, judges and scholars recognize Hamilton as an authoritative exponent of the Constitution's meaning. The underlying problem Barnett does not come to grips with is the phenomenon of framers and ratifiers disagreeing among themselves as to the original meaning of the Constitution.

110. BARNETT, supra note 1 , at 176-77.

111. For a useful discussion, see KathleEn M. Sullivan \& Gerald Gunther, CONSTITUTIONAL LAW 98-100 (14th ed. 2001).

112. BARNETT, supra note 1 , at 107. 
inappropriate. ${ }^{113}$ Deferential review, such as the use of the "rational basis" standard, would grant Congress an "unlimited discretion"114 to do as it sees fit.

Here Barnett runs together several issues that should be kept distinct. There is little doubt that the judiciary can take cognizance of whether Congress has violated the Necessary and Proper Clause. But the availability of judicial review has no obligatory implications for the standard of review that the Court should apply. Further, the lack of what Barnett would regard as meaningful review does not mean that Congress is at liberty to do whatever it wants. Members of the founding generation, such as James Madison, were quite clear on this point. ${ }^{115}$ Because the people were the ultimate sovereign, they were also the ultimate backstop should the checks and balances specified in the Constitution fail. Finally, Barnett is ignoring the issue of the relative institutional competence of the judiciary, an issue that became important during the Lochner era, as I discuss below.

Barnett then considers the meaning of the word "proper" in the Necessary and Proper Clause. Following an article by Lawson and Granger, ${ }^{116}$ he contends that "proper" means that the law must not violate principles of separation of powers and federalism and also must not violate background rights retained by the people. ${ }^{117} \mathrm{~A}$ law is also improper under the Necessary and Proper Clause if it is "intended by Congress to accomplish an improper end," "118 one not sanctioned by the enumeration of powers in Article I, section 8.

Barnett next turns to the question of whether the Privileges or Immunities Clause of the Fourteenth Amendment is a meaningful restriction on the power of state governments. He criticizes the Slaughter-House Cases for deviating from the original meaning of the Privileges or Immunities Clause as shown by the congressional debates. ${ }^{119} \mathrm{He}$ endorses the position taken by the dissenters that the purpose of the Privileges or Immunities Clause was to secure the liberties of contract

113. See id. at $178-84$.

114. Id. at 179 .

115. See The FEDERAlist No. 44, supra note 105, at 302-05.

116. Gary Lawson \& Patricia B. Granger, The "Proper" Scope of Federal Power: A Jurisdictional Interpretation of the Sweeping Clause, 43 DUKE L.J. 267, 271-73 (1993).

117. BARNETT, supra note 1 , at 186.

118. Id. at 189.

119. Id. at 195-202. 
and property. ${ }^{120}$ Barnett notes that this view was eventually vindicated in the Supreme Court's "economic" substantive due process jurisprudence in the Lochner era. ${ }^{121}$ Thus, for Barnett, the textual criticism of the Court's "substantive" due process jurisprudence during the Lochner era is largely beside the point. Because he believes that the Privileges or Immunities Clause of the Fourteenth Amendment explicitly authorizes the Court to carry out judicial review of state legislation to see whether rights of contract and property (among others) have been violated, the "doctrine of 'substantive due process' restores rather than violates the original historical meaning of section 1 of the Fourteenth Amendment taken as a whole from the damage done by Slaughter-House."122 Barnett thus comes to praise Lochner-era jurisprudence, not to bury it.

Barnett's discussion of Lochner-era jurisprudence is prefaced by some observations on the larger historical forces that influenced legislation and the courts during this period. He names some ideological shifts such as "the rise of scientific empiricism," mass immigration, and the influence of "the German socialist model."125 Barnett also believes that the Civil War "enhanc[ed] the moral authority of the central government." 126 Indeed, he goes further to contend that the Civil War reversed the traditional American distrust of centralizing government. ${ }^{127}$ These comments are more interesting for what they show about Barnett's point of view than their limited relation to what historians regard as the most important developments of the PopulistProgressive era. ${ }^{128}$

One important development Barnett does not mention that belongs to any history of postbellum America was the rise of industrial capitalism

120. Id. at 198

121. Id. at 203.

122. Id. at 208 .

123. Id. at 204.

124. Id.

125. Id.

126. Id.

127. Id. at 204-05.

128. For a recent useful overview, see Michael McGerr, A Fierce Discontent: The Rise and Fall of the Progressive Movement in America, 1870-1920 (2003). Legal historian William Wiecek has developed an alternative list of the important changes that had an effect on law during this period: (1) nonagricultural production now took place in factories rather than workshops; (2) widespread formation of labor unions, with fierce resistance by employers; (3) emergence of corporate capitalism; (4) increase in influence of investment banking firms or finance capitalism; and (5) formation of national economic and professional organizations. WILLIAM M. WIECEK, THE LOST WORLD OF ClAsSiCAL LEGAL THOUght: LAW AND IDEOLOGY IN AMERICA, 1886-1937, at 65 (1998). On the persistence of localism in American government after the Civil War, see Morton Keller, Affairs of State: Public Life in Late Nineteenth Century AMERICA (1977). 
and what was called the "Labor Question."129 From a constitutional perspective, the question that troubled many was how republican government was consistent with the rise of a permanent class of subordinate laborers who had no realistic prospect of being proprietors or entrepreneurs. Without some reference to this important issue, Barnett does not have a sure footing to understanding the constitutional background of the Lochner era.

Barnett refers, somewhat mysteriously, to "the pervasiveness of political motives in conflict with the original constitutional scheme of limited powers." ${ }^{130}$ He argues that, in such a situation, the courts could not simply defer to legislative findings that it was necessary to regulate economic activity on the basis of the police power. ${ }^{131}$ Barnett defends the Lochner decision as embodying the conception of privileges or immunities held by the framers of the Fourteenth Amendment. ${ }^{132}$ Like a number of contemporary scholars, Barnett rejects Justice Holmes's dissent as being out of step with both the jurisprudence of the early twentieth century and our own. ${ }^{133}$ He notes the existence of exceptions to the liberty of contract doctrine, but says that the fact that the right existed negated any implication that the Court necessarily had to defer to the legislature. ${ }^{134}$ According to Barnett, the Court in the Lochner era was following the proper course of action, observing what he calls "the presumption of liberty" and holding legislatures to high standards of proof. He notes that the presumption was occasionally successfully rebutted, as in Muller $v$. Oregon, ${ }^{135}$ the case that featured the famous "Brandeis brief.", 136

I agree with several themes in Barnett's discussion of the Lochner era, if not his evaluation of Lochner itself. I agree that the Privileges or Immunities Clause has a substantive meaning beyond that recognized in the Slaughter-House Cases. ${ }^{137}$ I agree also that Lochner was at least

129. See William E. Forbath, Caste, Class, and Equal Citizenship, 98 Mich. L. REv. 1, 25-51 (1999).

130. BARNETT, supra note 1 , at 211.

131. Id.

132. Id. at 215.

133. Id. at $214-17$.

134. Id. at 218.

135. 208 U.S. 412, 423 (1908) (upholding the constitutionality of state law restrictions on the working hours of females).

136. BARNETT, supra note 1 , at 218-19.

137. 83 U.S. (16 Wall.) 36 (1873) (affirming the decision that Lousiana had the exclusive right to determine slaughterhouse locations under its police powers and that the 
defensible by the legal norms that existed at the time, as demonstrated by Howard Gillman and many other historians. ${ }^{138}$ Barnett emphasizes Gillman's work in order to show that Lochner was supported by the original meaning of the Due Process Clause. ${ }^{139}$ On the other hand, Barnett does not give much attention to considering why Lochner and the Lochner era were and continue to be controversial.

If so much of what happened in the Lochner era was supported by precedent and our constitutional tradition, how is it that this era also saw the emergence of a still powerful critique emphasizing democratic limits on judicial power? To my mind, historians and legal scholars have not yet fully answered this question. However, it appears that the circumstances of the early twentieth century were fertile grounds for doubts about the way the constitutional system was working. ${ }^{140}$ Growing numbers of lawyers and legal scholars were becoming alienated from the constitutional tradition that Lochner represented. To give one example, even before the Lochner era had properly begun, law students such as future judge Learned Hand were absorbing the lesson of skepticism about rule by the judiciary from influential teachers such as Harvard's James Bradley Thayer. ${ }^{141}$ Indeed, Hand wrote one of the most influential contemporary critiques of the Lochner decision. ${ }^{142}$

As demonstrated by Hand, part of the problem was that there was plenty of evidence that the Court disagreed with the legislation as a matter of policy, not just constitutional principle. The Court showed an "ill-concealed hostility toward the trend to regulate employer-employee relations for the latter's protection." ${ }^{413}$ For Hand, the question of the economic merits of laws restricting hours of work were for the legislature to determine. ${ }^{144}$ Hand said that what was required was experimentation with the right balance in employer-employee relations, and the judiciary was unsuited for this task. ${ }^{145}$ Crucially, Hand commented: "That the legislature may be moved by faction, and without justice, is very true, but so may even the court. There is an inevitable bias upon such vital questions in all men, and the courts are certainly

Federal Constitution did not apply).

138. See GILLMAN, supra note 4, at 10-12. For discussion, see GRIFFIN, supra note 48, at 99-104.

139. BARNETT, supra note 1 , at 222.

140. Id. at 211 .

141. Gerald Gunther, Learned Hand: The Man And the Judge 50-53 (1994).

142. Learned Hand, Due Process of Law and the Eight-Hour Day, 21 HARV. L.

REV. 495 (1907-1908).

143. GUNTHER, supra note 141, at 120.

144. Id. at 121 .

145. Id. at 122 . 
recruited from a class which has its proper bias, like the rest."

Class conflict and, in particular, the often violent conflicts between labor and capital during this period posed a grave challenge to the continuity of the American constitutional tradition. The judiciary could accommodate this change up to a point, but on the question of whether laws regulating conditions of labor were constitutional, judges found it difficult to steer a path that would give something to both sides. As Hand perceived, the consequence was that the rule of law was no longer understood to be neutral. Once this occurred, a univocal constitutional tradition could not be maintained. Eventually, during the New Deal, the new tradition represented by judges like Hand and Chief Justice Harlan Stone won the day. ${ }^{147}$

Barnett then assesses the origins of the presumption of constitutionality. He believes that the presumption was used to evade the requirement of showing that legislation was a true necessity under the Necessary and Proper Clause. ${ }^{148}$ Here Barnett telescopes a great deal of doctrinal development to contend that the advent of the presumption of constitutionality and rational basis review threatened to "swallow the entire constitutional practice of judicial review."149 In his view, the Carolene Products footnote ${ }^{150}$ was necessary in order to establish a meaningful role for the Court in a post-necessary and proper world. Barnett calls this world "Footnote Four-Plus," the label signifying that, after Griswold v. Connecticut, the Court was willing to protect those rights enumerated in the Constitution, plus other specific unenumerated rights under a revived substantive due process doctrine. ${ }^{151}$

Barnett considers Footnote Four-Plus to be a pretty thin recipe for constitutional rights. He believes that the Ninth Amendment provides a firm foundation for protecting many rights beyond those recognized in the Footnote Four-Plus regime. ${ }^{152}$ He steps back to describe four approaches judges can take toward legislation that violates constitutional rights. The first is judicial deference- the presumption of constitutionality

146. See Hand, supra note 142, at 508.

147. There is an important article on this point by Robert McCloskey that Barnett does not cite. See Robert G. McCloskey, Economic Due Process and the Supreme Court: An Exhumation and Reburial, 1962 SuP. CT. REV. 34 (1962).

148. BARNETT, supra note 1 , at 225-28.

149. Id. at 229.

150. United States v. Carolene Prods. Co., 304 U.S. 144, 152 n.4 (1938).

151. BARNETT, supra note 1, at 232.

152. Id. at 234-42. 
should be applied to all legislation affecting rights. ${ }^{153}$ Second is the approach of Footnote Four to reverse the presumption when legislation infringes on rights specified in the Constitution. Among other problems, this approach conflicts with both the Ninth Amendment and the Privileges or Immunities Clause. ${ }^{154}$ Third would be the "Footnote FourPlus" approach that would add protection of some unenumerated rights.

None of these alternatives suit Barnett. His preferred approach is "to protect all the rights retained by the people equally whether enumerated or unenumerated." " retained unenumerated rights. Barnett's general method, of course, is to search historical evidence for the original meaning of the text. There is certainly no shortage of historical materials from the eighteenth century on the subject of rights. But Barnett also believes, consistent with members of the founding generation, such as James Wilson, that "it is impossible to specify in advance all the rights we have."156 The best way to deal with this inability to specify all the rights of liberty is not to work harder at constructing a list, but rather to embrace the "Presumption of Liberty." "157 Under this presumption, the government has the burden "to establish the necessity and propriety of any infringement on individual freedom." 158

Barnett believes the presumption of liberty has several advantages. It is consistent with the original meaning of the text. ${ }^{159}$ Courts will no longer have to decide which rights merit "fundamental" status, as they currently do under the substantive due process doctrine. ${ }^{160}$ But he also believes that the new presumption is justified by our experience with how legislatures work. He says that the presumption of constitutionality was based on the idea that legislatures would carefully consider constitutional protections of liberty before infringing rights. ${ }^{161}$ We have learned, however, how the interest group state really works. Sometimes legislation serves majority interests, sometimes minority interests, but the legislature rarely cares about whether statutes meet the "necessary and proper" standard. ${ }^{162}$ Judicial review is required to bring the constitutional system back into balance to prevent legislatures from

\footnotetext{
153. Id. at 253.

154. Id. at 253-54.

155. Id. at 254 .

156. Id. at 259 .

157. Id.

158. Id. at 260.

159. Id.

160. Id.

161. Id.

162. Id.
} 
being the sole judges of their own powers. ${ }^{163}$ At this point, Barnett's argument contains more than an echo of the eighteenth century distinction between reason and will: ${ }^{164}$ "Without judicial review, statutes are mere exercises of will, and are not entitled to the same presumption of respect that attaches to statutes surviving meaningful scrutiny.”165 Barnett's position might be summarized as strict scrutiny across the board.

It is strict scrutiny, however, with a certain structure. To satisfy the presumption of liberty, laws must be shown either to "prohibit wrongful or regulate rightful activity ...."166 Wrongful activity is an action that violates the rights of others. ${ }^{167}$ The baseline for distinguishing rightful from wrongful conduct is basically the common law. Barnett imports the standards of private law in order to make sense of what the presumption of liberty means for constitutional law. He allows legislative alteration of common law rights, but with judicial review to ensure that the legislative purpose is to "correct doctrinal errors"168 rather than "invade individual rights." 169 In general, if legislation is designed to attain a "desirable social policy"170 rather than prohibit wrongful behavior or regulate rightful behavior, it will be beyond the power of the legislature and hence unconstitutional.

The presumption of liberty would obviously place more power in the hands of judges. Barnett acknowledges this only to say immediately that it is unavoidable ${ }^{171}$ (this is not very reassuring). ${ }^{172}$ In general, Barnett

163. Id. at 261.

164. See generally PAUl W. KAHN, LEGITIMACY AND HiSTORY: SELF-GOVERNMENT IN AMERICAN CONSTITUTIONAL THEORY 98-99 (1992) (discussing two antebellum understandings of the Constitution: as a "practical application of an abstract science of politics" and as a "historically unique expression of the will of the popular sovereign").

165. BARNETT, supra note 1, at 261.

166. Id. at 262 .

167. Id.

168. Id. at 263.

169. Id. at 264 .

170. Id. at 265 .

171. Id. at 266 .

172. Barnett's position on checking the judiciary is puzzling. He writes that if judges overstep their bounds enforcing the natural liberties of all, they may be checked by constitutional amendment or even the judicial appointment process. Id. at 268. This is a strange concession for a libertarian to make. To stay consistent, Barnett should be searching for ways to make it impossible to place nonlibertarian judges on the bench. Otherwise, their constitutionally valid decisions would be overturned as soon as they became unpopular with the people. Barnett objects to the idea of voting on what rights we have, but allowing judges to be checked through the appointment process would have the same effect. 
has trouble seeing the point of institutional objections to increased judicial power and the influence these objections have had over theories of judicial review since scholars like Thayer and Hand first advanced them. ${ }^{173}$ This is directly relevant to the way he develops his argument in favor of the presumption of liberty. The justification for the presumption of constitutionality was rooted in the experience of the Lochner era with the institutional limitations of courts, not, as Barnett believes, out of an expectation that legislatures would always behave constitutionally. The Lochner generation learned that it was difficult to tell whether legislation was invading protected rights or promoting a desirable social policy. In addition, lawyers and judges discovered that the common law did not provide any way to address complex social and economic problems. Legislation could therefore not be confined, as Barnett would have it, to correcting the occasional judicial error.

Barnett tries to defend the Lochner era without confronting any of the most substantial reasons why generations of lawyers since have thought it represented a deeply flawed judicial attempt to obstruct legislative efforts to deal with important social problems. His reconstruction of how the principles of the Lochner era could operate in our own time through the presumption of liberty is interesting but ultimately fruitless in the absence of an attempt to come to grips with the most common critiques of the Lochner era.

\section{The Commerce Clause and the State Police Power}

In the last part of the book, Barnett considers specific constitutional powers such as the federal government's power to regulate the economy under the Commerce Clause. From his point of view, it is the Commerce Clause "that has most often been used by Congress to restrict the liberties of the people." ${ }^{\text {"174 }}$ Barnett considers two alternative interpretations of the commerce clause: the pre-New Deal understanding that it is "limited to trade or exchange of goods"175 and excludes manufacturing and agriculture, and a broad interpretation that it applies "to any gainful activity." "176 It is puzzling that Barnett does not consider an obvious alternative: that "commerce" in the context of today's national economy means commercial activity. ${ }^{177}$

173. For a recent example of an institutional analysis of the limitations of the judiciary, see Cass R. Sunstein, One CASE AT a Time: Judicial Minimalism on the SUPREME COURT 46-60 (1999) (arguing that good judges attempt to minimize potentially adverse effects of their holdings by adopting change incrementally).

174. BARNETT, supra note 1 , at 277.

175. Id. at 278.

176. Id.

177. See United States v. Lopez, 514 U.S. 549, 558-59 (1995). 
Barnett argues with plentiful evidence that the original meaning of the commerce clause validates pre-New Deal understandings that it excluded regulation of agriculture or manufacturing. He endorses the reading of the Commerce Clause the Supreme Court gave in United States v. E.C. Knight Co. ${ }^{178}$ and Carter v. Carter Coal Co. ${ }^{179}$ As a historical matter, I can hardly disagree, because I have defended elsewhere ${ }^{180}$ the idea that the New Deal understanding of the commerce clause as a broad charter to regulate the economy did not have anything to do with Chief Justice Marshall's understanding of its more limited purpose in Gibbons v. Ogden. ${ }^{181}$ As Barnett notes, even on Marshall's understanding, commerce "among the several States" did not include purely intrastate commerce. ${ }^{182}$ Although New Dealers such as future justice Robert Jackson saw themselves as restoring the original understanding of the Commerce Clause, their arguments are not supported by historical evidence. ${ }^{183}$

Barnett goes on to argue that the original meaning of "to regulate" in the Commerce Clause did not include the power to prohibit goods from moving in interstate commerce. ${ }^{184}$ He excoriates the "aggregate effects" doctrine recognized in Wickard v. Filburn ${ }^{185}$ as having "nearly destroyed the system of limited enumerated powers." "186 He also rejects the "articles of commerce" doctrine that allows Congress the power to regulate activity based on goods that have moved in interstate commerce. ${ }^{187}$ He claims that "an interconnected economy was far from unforeseen by the founders" ${ }^{\prime 88}$ on the basis of a single quotation from James Madison. ${ }^{189}$ Barnett appears to be claiming that the framers saw

178. 156 U.S. 1,16 (1895).

179. 298 U.S. 238, 301 (1936). Barnett also endorses Justice Thomas's concurrence in Lopez, in which Thomas argued in favor of reestablishing the pre-New Deal understanding of the commerce clause. Lopez, 514 U.S. at 596 (Thomas, J., concurring).

180. See Griffin, supra note 6, at 2121-42.

181. 22 U.S. (9 Wheat.) 1 (1824).

182. BARNETT, supra note 1 , at 297.

183. See generally Griffin, supra note 6.

184. See BARNETT, supra note 1 , at 302-06.

185. 317 U.S. 111, 125 (1942).

186. BARNETT, supra note 1 , at 315.

187. Id. at 316.

188. Id. at 315 .

189. In the midst of his argument about the meaning of the Necessary and Proper Clause, Barnett pauses to claim that Madison realized, just as we do, "that the national economy is interconnected.” Id. at 172 . This claim is supported by a letter written by 
the consequences of a commerce clause limited to the trade of goods among states and rejected the alternative of allowing Congress a broader power to regulate the national economy. This is highly doubtful, because a national market in which agriculture and manufacturing were key sectors of an interstate commercial economy did not exist in the eighteenth century.

Barnett's discussion of the Commerce Clause is so aggressively rooted in the different economic world of the eighteenth century that it enables us to see the tremendous distance between that world and our own. I therefore agree with Barnett that the New Deal marked a true "revolution, not a restoration"190 in constitutional law. ${ }^{191}$ The problem is then to explain how the New Deal revolution was legitimate, given that it was not made through an Article $\mathrm{V}$ amendment to the text of the Constitution.

For Barnett, of course, this is not a problem but an opportunity to show how commerce clause doctrine cannot be made legitimate except by returning to the pre-New Deal understanding that agriculture, manufacturing, and conditions of labor are beyond the regulatory power of the federal government. If this poses a problem for the operation of the economy and workplace conditions, Barnett thinks it is better to require a constitutional amendment, rather than (as was done during the New Deal) changing the meaning of the Constitution through judicial fiat. ${ }^{192}$ Throughout the book, Barnett seems to assume that if Americans dislike the implications of restoring the Constitution that was "lost" through Supreme Court interpretation, they will find it relatively easy to pass constitutional amendments to update the text in light of contemporary circumstances. ${ }^{193}$ The experience of the New Deal can help us understand why this assumption is problematic.

Madison to Judge Roane in which he stated:

In the great system of political economy, having for its general object the national welfare, everything is related immediately or remotely to every other thing; and, consequently, a power over any one thing, if not limited by some obvious and precise affinity, may amount to a power over every other thing.

Id. This claim is not plausible and is not supported by this evidence. It is not plausible because the economy of the late nineteenth and early twentieth century that caused judges and scholars to think that times had changed did not exist in 1819, when Madison wrote this letter. The economy of 1819 was predominantly agrarian and not dominated by large industrial corporations. Further, it is likely that Madison's point was logical, not empirical. One plausible reading of this passage is that Madison was claiming that in "political economy," there was at least a remote causal connection between every person. This does not entail the further set of claims characteristic of modern commerce clause jurisprudence, such as those made in cases that upheld New Deal legislation.

190. Id. at 332.

191. See Griffin, supra note 6, at 2117-19.

192. BARNETT, supra note 1 , at 352-53.

193. Id. at 351 . 
Although Barnett notes in passing that President Franklin D. Roosevelt rejected the option of seeking an amendment to justify the changes he sought, ${ }^{194}$ he does not consider the possibility that this outcome was dictated by the structure of the constitutional order, rather than just being a missed opportunity. ${ }^{195}$ In assessing potential amendments, Roosevelt was not writing on a blank slate but rather operating in a context created by Supreme Court decisions. This complicated his task considerably. The "Old Court" that was hostile to the New Deal would presumably be in charge of interpreting any constitutional amendment. If the amendment was drafted in broad terms, the Court might be able to undermine it through a narrow construction of its general provisions. If the amendment was drafted narrowly to overturn specific precedents, then it might not apply to all the circumstances in which the government needed new powers. ${ }^{196}$

In addition, by the time of the New Deal it was no longer possible for anyone to view the Constitution as a practical plan of government in the same way as the founding generation. By now, the Constitution was revered as the cornerstone of the American political system. That made the Constitution an exceptionally stable basis for government, but also made it very difficult to change. ${ }^{197}$ The Constitution was seen as an ideal by which government should be judged and was the focus of strong patriotic sentiments. These sentiments led Americans to see potential constitutional amendments as implying that the American constitutional and political order was defective. President Roosevelt had no intention of leading Americans to believe that their most fundamental institution was flawed. Hence, he opted for the position that the problem was with the Court, not the Constitution. ${ }^{198}$

Barnett assumes that if the Constitution needs to be updated in light of changing circumstances, such as our desire to regulate labor unions and workplace conditions, it can be changed in much the same way as we update obsolete statutes. If, however, the Constitution is resistant to even reasonable changes, then this stance becomes problematic. It is possible that Barnett would not see this as a problem, but as evidence that there is no need for change in the first place. On the other hand, he

\footnotetext{
194. Id. at 109.

195. GRIFFIN, supra note 48, at 37-39.

196. Id. at 38 .

197. Id. at 39.

198. Id.
} 
does not offer any argument to persuade those who see regulating conditions of labor as a reasonable adaptation of the Commerce Clause to changed circumstances. Indeed, Barnett's entire argument on the Commerce Clause is notably devoid of detail on just what liberties are being infringed by the contemporary understanding that it is a broad charter to regulate interstate commercial activity. What would we gain if we returned to pre-New Deal baselines? Barnett asserts that the Commerce Clause has most often been the instrument through which Congress restricts the liberties of the people. ${ }^{199}$ I doubt, however, that anyone sees it that way except for libertarians who already agree with Barnett's political theory.

Barnett then considers the effect of the presumption of liberty on the state police power. From the perspective of the federal Constitution, state police powers are limited primarily by the Fourteenth Amendment. But Barnett has trouble specifying the nature of the limits on the state police power because he does not believe that the liberties protected by the Privileges or Immunities Clause can be reduced to a list. His method is to test all legislative enactments by whether they are necessary and proper, yet there is no list of the enumerated powers of state legislatures in the Constitution. ${ }^{200}$ This poses an interpretive problem that he wants to solve by using his version of "constitutional construction," the method we must employ when we are forced to go beyond original meaning. ${ }^{201}$ Barnett does not consider whether he has been led astray by his assumption that all exercises of constitutional power must have limits, whether or not those limits are specified in the Constitution. A more standard approach to the state police power is that it is not based on the idea of enumerated power at all, but is grounded on a plenary delegation of reserved powers to the states, as confirmed by the Tenth Amendment.

For reasons that are difficult to discern, Barnett tries to specify the meaning of the state police power by taking an excursus into "Lockean political theory." 202 This leads him to conclude that the theory behind the Fourteenth Amendment is roughly consistent with the natural rights theory behind the 1787 Constitution. ${ }^{203}$ He does note that the police power was often construed to encompass efforts to control the morals of the public as well as to preserve its health and safety. ${ }^{204}$ Barnett thinks that this was a mistake and that the police power ought not to extend so far. He then employs Howard Gillman's historical research to build a

199. BARNETT, supra note 1, at 277.

200. Id. at 321 .

201. Id.

202. Id. at 327.

203. Id. at 328 .

204. Id. at 329. 
case that the police power of the states cannot be used to benefit a particular class of persons. ${ }^{205}$

In his final chapter, Barnett sets out a scheme for courts to follow in assessing the necessity and propriety of legislation. He takes his inspiration from First Amendment jurisprudence. To assess necessity, the government must show a sufficient fit between means and ends and then demonstrate that it used the means least restrictive of liberty. ${ }^{206}$ Interestingly, he more or less abstains from trying to illustrate the implications of his theory for constitutional doctrine. As a constitutionalist, Barnett is hard core: get the structure right, he thinks, and let the results take care of themselves. $^{207}$ After all, if we do not like the consequences, we can always amend the Constitution. He does not consider the possibility that changing the Constitution through amendment is not a practical option.

Barnett does give a few illustrations of the effect of following the presumption of liberty. From his point of view, the presumption is already followed in First Amendment and substantive due process jurisprudence. $^{208}$ If the presumption were to be extended further, in the manner his theory suggests, all crimes of possession, whether directed at firearms, drugs, or pornography, would be unconstitutional. ${ }^{209}$ They are unconstitutional at the federal level because the Commerce Clause does not permit Congress to prohibit their possession. ${ }^{210}$ They are unconstitutional at the state level because the state police power does not extend to actions that do not pose a risk of violating the rights of others. ${ }^{211}$ Further, efforts to regulate interstate pollution that result from manufacturing or agriculture cannot be handled within the boundaries of the present Constitution. ${ }^{212}$ Barnett thinks a constitutional amendment is necessary to handle the problem of pollution and that one would be ratified easily. ${ }^{213}$

Some of the most troubling implications of Barnett's theory come from its restoration of pre-New Deal constitutional baselines. So conditions of labor would be once again off limits to national legislation

\footnotetext{
205. Id. at 331-33.

206. Id. at 336 .

207. Id. at 345 .

208. Id. at 347.

209. Id. at 349 .

210. Id. at 348-49.

211. Id.

212. Id. at 350-51.

213. Id. at 351.
} 
because labor contracts are somehow not commerce or indispensable elements of interstate commercial enterprises. ${ }^{214}$ Unlike the example of interstate pollution, Barnett does not favor a constitutional amendment to allow regulation of conditions of labor. From his point of view, minimum wage laws and presumably much of the regulation of conditions of labor should remain off-limits to the national government. Again, while libertarians presumably need no persuasion on this score, those who think New Deal style regulation of labor conditions was long overdue will not find any arguments to persuade them in Barnett's book.

\section{CONCLUSION}

In his conclusion, Barnett affirms that "[t]he original meaning of the entire Constitution, as amended, is much more libertarian than the one selectively enforced by the Supreme Court." ${ }^{215}$ He feels that this is compelled by the evidence he has assembled of the Constitution's original meaning. But Barnett cannot explain why we have departed from the original meaning. He cites "political agendas" ${ }^{216}$ without being specific.

There is something incongruous about theories that claim that we have "lost" the true meaning of the Constitution. ${ }^{217}$ If Barnett is right, we began losing the original meaning of the Constitution almost immediately after the government began operating in 1789. Surely it is more plausible that the founding generation began disagreeing about the meaning of the Constitution, not that they deliberately set about "losing" it. We have been disagreeing in principle ever since. But disagreement does not involve losing anything. Rather, when we began disagreeing, we found a tradition in which we could all participate while maintaining fidelity to the Constitution.

214. Id. at 352.

215. Id. at 356

216. Id.

217. For another theory in a similar vein, see RoBert H. BoRK, THE TEMPTING OF AMERICA: The Political SEDUCTION OF THE LAW (1990) (arguing that the integrity of the law has been undermined by judges viewing the Constitution as a malleable text that can be rewritten to suit pressing social agendas). 